\title{
BUDAYA BANYUMASAN TAK SEKADAR DIALEK (REPRESENTASI BUDAYA BANYUMAS DALAM PROSA KARYA AHMAD TOHARI)
}

\section{Imam Suhardi}

\section{Pengantar}

Pelestarian budaya Banyumasan kembali bergaung di jagat penginyongan. Beberapa diskusi dan lokakarya tak urung membicarakan hal itu. Semakin memudarnya penggunaan dialek ngapak-ngapak (sebagai subsistem budaya) di kalangan generasi muda menjadi perbincangan hangat beberapa budayawan Banyumas. Padahal, bahasa Banyumasan merupakan aset budaya yang sangat penting. Istiyani (2004:6) menyatakan bahwa pandangan dunia adalah perefleksian pengalaman, pengetahuan, dan pemahaman dalam bentuk bahasa yang merupakan hasil penerimaan rangsangan dari alam sekitar melalui pancaindranya. Pandangan dunia komunitas bahasa dapat ditentukan dengan memeriksa sejumlah kosakata (Suhandano, 2004 dalam Syarifuddin, 2008:41). Berdasar pada teori tersebut dapat dikatakan bahwa Bahasa Banyumas sebagai sistem lingusitik sudah tentu memiliki pola khas yang akan merujuk pada pola dasar metalitas (basic assumption) masyarakat Banyumas.

Berdasarkan catatan E.M. Uhlenbeck, disimpulkan bahwa bahasa Banyumasan terbagi menjadi empat subdialek utama. Subdialek itu meliputi wilayah utara (Tegalan), wilayah selatan (Banyumasan), wilayah CirebonIndramayu (Cirebonan), dan wilayah Banten Utara. Dialek wilayah utara dituturkan antara lain di Tanjung, Ketanggungan, Larangan, Brebes, Slawi, Moga, Pemalang, Surodadi, dan Tegal. Dialek wilayah selatan dituturkan di wilayah Bumiayu, Karang Pucung, Cilacap, Nusakambangan, Kroya, 
Ajibarang, Purwokerto, Purbalingga, Bobotsari, Banjarnegara, Purworejo, Kebumen, serta Gombong. Dialek Cirebon-Indramayu dituturkan di sekitar Cirebon, Jatibarang dan Indramayu (http://id.wikipedia.org/ wiki/Bahasa_Jawa_Banyumasan). Tak pelak, dalam bahasa Banyumasan terdapat beberapa variasi morfem yang memiliki kemiripan. Sebut saja, "kepriwe", "keprimen”, atau "kepriben".

Pada dasarnya bahasa banyumasan adalah subdialek bahasa Jawa, selain dialek Solo-Yogyakarta, Surabaya, Madiun-Kediri, Banyuwangi, Semarangan, Cirebon-Indramayu, dan Banten. Bahasa Jawa mengenal tingkatan dalam penggunaannya yaitu ngoko, krama, dan krama inggil. Meski demikian, Orang-orang Banyumas umumnya lebih suka menggunakan bahasa ngoko atau ngoko andhap, khususnya bagi sesama Banyumas karena dirasakan lebih akrab. Bahasa kromo atau kromo inggil digunakan sesekali saja. Sebab, setelah tahu yang diajak bicara adalah satu daerah, orang Banyumas biasanya kembali menggunakan bahasa ngoko. Orang-orang yang tinggi pangkatnya pun dapat akrab dengan masyarakat awam dengan bahasa tersebut. Hal ini terjadi karena letak Banyumas yang jauh dari lingkungan keraton sehingga pengaruh unggah-ungguh belum begitu kuat (Koderi, 1991: 165).

\section{Orang Banyumas Malu Menggunakan Dialeknya}

Sebuah ironi, masyarakat Banyumas kini justru semakin beringsut mundur dari bahasa induknya. Adanya anggapan bahwa bahasa Banyumas sebagai bahasa kaum jongos (pembantu) menyebabkan kaum muda di Banyumas enggan menggunakan dialeknya. Mereka bahkan minder dan malu.

Berbagai upaya dilakukan sebagai respons atas kemirisan fenomena tersebut. TD Sudjana, misalnya. Dia selalu mewacanakan mata pelajaran bahasa daerah tidak dihapus dari muatan lokal kurikulum pendidikan nasional. Sementara itu di Jatilawang Ahmad Tohari bersama budayawan M. Koderi dan Fadjar P bersibuk-sibuk menyusun Kamus Dialek Bahasa Banyumas-Indonesia. Ahmad Tohari bahkan mulai menerjemahkan novel-novelnya, seperti Bekisar Merah versi Banyumasan (Jegingger) setelah Ronggeng Dukuh Paruk versi Banyumasan.

Ya, bahasa dan sastra Banyumasan memang harus dijaga agar tidak terpinggirkan, minimal oleh masyarakat penuturnya. Apalagi bahasa Banyumasan memiliki kedekatan langsung dengan bahasa Jawa Kuna 
yang menjadi cikal bakal bahasa orang Jawa Tengah. Beberapa bukti menunjukkan, kekhasan vokal "a" dalam bahasa Banyumasan terdapat pula pada artefak-artefak Borobudur zaman Syailendra. Sebagai contoh, "inyong" dan "sira" dalam bahasa Banyumasan sepadan dengan "ingong" dan "sira" dalam bahasa Jawa Kuna.

\section{Representasi Budaya Banyumas dalam Karya Prosa Ahmad Tohari}

Harus diakui bahwa sastra Banyumasan senantiasa terkait dengan dialek "ngapak-ngapak". Sastra memang tidak bisa dilepaskan dari bahasa sebagai medianya. Tambahan pula, bahasa adalah subsistem kebudayaan yang memiliki pola-pola mental pelaku budayanya. Artinya, masyarakat yang berdialek Banyumasan akan memiliki cara perilaku dan sikap metal yang berbeda dari masyarakat yang berdialek lain.

Dialek Banyumasan cenderung bersifat egaliter, lugas, dan sederhana. Tidak ada klasifikasi feodalistik dalam bahasa ini. Tingkat bahasa sebagaimana dalam bahasa wetanan (Solo,Yogya, Semarang) tidak begitu tampak. Karena itu, sudah sepatutnya roh dialek tersebut juga terdapat dalam kesusastraan Banyumasan.

Ya, tanpa mengesampingkan ngapak-ngapak sebagai ciri khas Banyumasan, keberadaan roh cablaka dalam dialek itulah yang semestinya lebih ditekankan dalam kesusastraan Banyumas. Eforia bahasa daerah memang perlu, tetapi harus diletakkan dalam kerangka yang jelas demi suatu tujuan. Apalagi kesusastraan menyediakan begitu banyak ruang untuk mengangkat nilai-nilai budaya.

Pemanfaatan unsur intrinsik prosa adalah salah satunya. Itulah sebab novel-novel Ahmad Tohari begitu elok. Novel Di Kaki Bukit Cibalak, misalnya. Melihat beberapa diksi yang digunakan pengarang pada paragraf awal, pembaca luar pelaku dialek Banyumasan akan segera mengernyitkan dahi. Sebab dalam paragraf tersebut Tohari langsung memunculkan beberapa istilah banyumasan, sebagai contoh, "korakan", "botoh", "belukar puyengan", "bengkok modin".

Dulu jalan setapak itu adalah terowongan yang menembus belukar puyengan. Bila iring-iringan kerbau lewat, tubuh mereka tenggelam di bawah terowongan semak itu. Hanya bunyi korakan yang tergantung pada leher mereka terdengar dengan suara berdentangdentang, iramanya tetap dan datar. (Tohari, 2001: 5)

Sanis adalah anak modin di Tanggir. Ayah Sanis tidak memiliki 
tanah sedikit pun, kecuali sedikit tanah bengkok yang ia terima sebagai gaji seorang modin (Tohari, 2001: 9).

Tiap-tiap calon mempunyai beberapa orang botoh yang mempunyai tugas sebagai pengumpul suara. Soal cara, tidak diperhatikan benar. Maka para botoh inilah yang hampir selalu membuat keonaran pada setiap pemilihan pamomong desa. Sesungguhnya para botoh ini tidak pantas mendapat kepercayaan apapun. Mereka mau bekerja dengan satu tujuan, uang! (Tohari, 2001:15)

Berdasarkan tiga kutipan di atas dapat diketahui terdapat beberapa istilah: "puyengan", "korakan", "bengkok", dan "botoh" yang merupakan istilah khas pedesaan khususnya di wilayah Banyumas dan sekitarnya. Penggunaan istilah ini memang acap membuat pembaca harus berpikir untuk menggapai maknanya. Namun, perlu diperhatikan bahwa pemakaian istilah ini tidak dibiarkan berdiri sendiri tanpa penjelasan. Dalam masyarakat (Banyumas) istilah puyengan digunakan untuk merujuk wilayah sabana ilalang yang sangat luas, sebagaimana dideskripsikan dalam novel tersebut mampu menutupi tubuh kerbau-kerbau yang melewatinya. Demikian juga dengan istilah "korakan", bermakna sebuah lonceng kecil yang dikalungkan di leher kerbau untuk menandai keberadaan kerbau saat digembalakan di tanah terbuka. Penjelasan tersebut juga tampak dalam deskripsi berikut.

Hanya bunyi korakan yang tergantung pada leher mereka terdengar dengan suara berdentang-dentang, iramanya tetap dan datar. Burung-burung kucica yang terkejut, terbang mencicit. Mereka tetap tidak mengerti mengapa kerbau-kerbau senang mengusik ketenteraman belukar puyengan tempat burung-burung itu bersarang. Meski kerbau-kerbau itu telah jauh memasuki hutan jati Bukit Cibalak, suara korakan mereka masih tetap terdengar. Dan bunyi korakan adalah pertanda yang selalu didengarkan oleh majikan. (Tohari, 2001: 5)

Dalam kutipan di atas tampak novelis menjelaskan istilah korakan yang tentu sangat asing bagi pembacanya, terutama yang memiliki bahasa ibu bukan Jawa. Kutipan di atas secara implisit juga mendeskripsikan lingkungan satwa yang menjadi ciri khas daerah Banyumas dan sekitarnya. Hal tersebut tampak dalam penggunaan istilah "burung kucica" yang digambarkan terusik oleh keberadaan gerombolan kerbau yang melewati sarangnya. Sebagaimana diketahui, burung kucica atau lebih dikenal 
dengan kucica kampung atau Kacer (Copsychus saularis) adalah sejenis burung pengicau kecil yang sebelumnya dikelompokkan sebagai anggota keluarga Turdidae (Murai), tetapi kini dianggap sebagai anggota Muscicapidae. Burung ini berwarna hitam dan putih dengan ekor yang panjang. Ekornya terangkat ke atas jika mereka sedang mencari makanan di tanah atau kadang ketika sedang bertengger. Burung ini banyak ditemukan di wilayah Banyumas dan sekitarnya.

Kelugasan, kesederhanaan, egaliter, dan semangat kesatria adalah karakter stereotipe yang bisa diangkat untuk mewujudkan kekhasan karakter orang Banyumas. Hal ini juga diangkat oleh Tohari dalam beberapa karyanya, sebagai contoh tokoh Karyamin dalam cerpen "Senyum Karyamin".

Dalam cerpen "Senyum Karyamin" diceritakan bagaimana tokoh Karyamin selalu berusaha tersenyum meski himpitan ekonomi dan kelaparan mendera. Tokoh ini adalah stereotipe manusia yang memiliki semangat kesatria. Tokoh yang selalu menjunjung tinggi harga diri, meski realitas sering tidak berpihak padanya. Hal tersebut tampak saat ia menolak tawaran utang penjaja makanan, meski sesungguhnya ia dalam kondisi sangat lapar.

"Jadi sungguh kamu tidak mau makan, Min?" tanya Saidah ketika melihat Karyamin Bangkit.

"Tidak. Kalau kamu tak atahan melihat aku lapar, akupun tak tega melihat daganganmuhabis karena utangku dan kawan-kawan" (Tohari, 1989: 4)

Selain upaya deskripsi terhadap stereotipe karakter Banyumas, dalam beberapa ceritanya Tohari juga mencoba menunjukkan khasanah bahasa Banyumas melalui pemberian nama tokoh-tokoh fiksinya, seperti Kenthus, Blokeng, Cablaka, Kanjat, Bambung, dan Martacarub.

Sebagainya galibnya masyarakat Banyumas ketahui, istilah "kenthus" diambil dari "kementhus", yang merupakan perwujuan sifat sombong, congkak, dan suka meremehkan orang lain. Demikian juga "blokeng". Dalam khasanah bahasa Banyumas, "blokeng" adalah buah kelapa yang telah diambil air dan dagingnya, tinggal sabut dan tempurungnya. Blokeng tersebut biasanya dijemur beberapa hari dan dipakai oleh masyarakat Banyumas serupa kayu bakar. 
Dalam cerpen "Kenthus" dan “Blokeng”, Tohari sengaja membongkar aspek semantis "kementhus" dan "blokeng" ke dalam deskripsi karakter tokoh rekaannya. Dalam cerpen "Kenthus" tokoh tersebut digambarkan sebagai seorang buruh tani dan pencari kayu bakar yang terlalu bangga diri ketika mendapat kepercayaan dari ketua RT untuk menjadi koordinator pembasmian hama tikus di wilayahnya.

Kenthus bangkit. Kediriannya yang baru menggeliat sejak pulang dari rumah ketua RT tadi pagi, tersinggung. Dawet dilihatnya lebih kecil daripada liliput. Mulutnya lebih jelek dari dubur ayam. Kemudian Kenthus berpidato. Penuh gaya, lebih gaya dari penjual obat palsu di depan pasar. Dikatakannya, dia baru saja mendapat tugas, semacam wahyu cakraningrat, sebagai pelaksana proyek pengadaan buntut tikus (Tohari, 1989: 48)

Demikan pula dengan karakter Blokeng dalam "Blokeng". Tokoh tersebut digambarkan sebagai perempuan gila yang tinggal di dalam pasar. Tokoh ini diceritakan tiba-tiba hamil dan melahirkan anak perempuan. Seluruh warga pun gempar. Para lelaki takut dianggap bertanggung jawab atas kehamilan Blokeng.

Tetapi tentang si Blokeng memang tidak ada duanya. Kecuali dia adalah perempuan yang secara biologis sempurna -seperti baru saja terbukti - sama halnya dengan perempuan-perempuan lain. Selebihnya, siapapun tak sudi diperbandingkan apalagi dimiripkan dengan Blokeng. Ini kepongahan kampungkuyang dengan gemilang telah berhasil memelihara rasa congkak dengan cara memanipulasi nilai martabat kemanusiaan (Tohari, 1989: 33)

Deskripsi kutipan di atas menunjukkan bahwa Blokeng adalah karakter terbuang. Karakter yang hanya menjadi sampah bagi orangorang. Tohari tampak sengaja mengangkat kembali istilah sampah kelapa menjadi sebuah karakter Blokeng yang dimetaforakan ke dalam sosok yang dinistakan masyarakat dalam pergaulan sehari-hari.

Penggunaan bahasa banyumasan juga tampak pada novel Belantik. Aspek semantis dialek Jawa Banyumas tampak dijelaskan dalam beberapa nama tokoh dalam novel ini, seperti Bambung, Kanjat, Cablaka, Blakasuta, dan Martacarub.

Kata Bambung dalam Kamus Dialek Bahasa Banyumas-Indonesia berarti 
manusia sinting dan ngawur. Definisi leksikal tersebut dideskripsikan ke dalam tokoh Bambung sebagai berikut.

Jakun Handarbeni turun-naik. Rahangnya merapat. Bambung yang dikalangan sangat terbatas dikenal sebagai pelobi tingkat tinggi di Ibukota, baru saja bicara dalam gaya intrik yang penuh metafor dan luar biasa halus. Licin, melingkar, sekaligur menjerat. Licik. Bahkan menyandera seluruh jiwa. Kekuatan intrik itu terasa tak terelakkan meski diucapkan dengan selingan senda gurau (Tohari 2001:7).

Kutipan di atas menunjukkan karakter tokoh Bambung yang digambarkan oleh Handarbeni yaitu licik, penuh intrik, melakukan semua hal berdasarkan keinginannya, tampak sesuai dengan definisi semantis kata bambung.

Hal lain yang menguatkan kesamaan karakter tokoh Bambung dan makna semantis bambung adalah sebagaimana kutipan berikut.

Ada yang bilang sesungguhnya Bambung adalah agen tersamar sebuah konsorsium perusahaan minyak asing. Konon dialah orang yang mengatur siasat dan kongkalingkong, sehingga pintu untuk masuknya petrodolar ke Jakarta sesudah Bung Karno tersingkir terbuka (Tohari, 2001: 8).

Karakter tokoh Bambung di atas menunjukkan kenekatan. Tokoh ini tahu kongkalingkong yang terjadi di negerinya bisa merugikan bangsanya, namun itu tetap ia lakukan. Bahkan tokoh ini adalah gembong mafia perusahaan minyak. Inilah karakter tokoh Bambung yang menunjukkan sifat sebagaimana makna leksikal "bambung" yang berarti "ngawur".

Demikian pula dengan karakter tokoh Kanjat dalam novel tersebut. Kanjat dalam bahasa Banyumas berarti memuaskan, layak dan patut. Dalam novel dideskripsikan bahwa tokoh Kanjat berprofesi sebagai dosen di sebuah universitas negeri di Purwokerto. Dari sekian banyak pemuda desa di Karangsoga, Kanjat termasuk orang yang beruntung karena mampu mengenyam pendidikan hingga jenjang perguruan tinggi. Prestasi Kanjat itu dianggap mengangkat derajat desanya, Karangsoga. Hal tersebut secara implisit tampak pada kutipan berikut.

"Nah, ini yang namanya kebetulan. Aku senang kamu datang. Sejak pagi 
kutunggu, kamu tidak muncul. Ah, aku memang lupa kamu sudah jadi pegawai ...apa? Dosen?”... (Tohari, 2001: 76).

Kemudian Lasi menyesali dirinya karena lupa saat itu tengah malam dan nomor yang diputar adalah milik kampus Universitas Jenderal Soedirman tempat Kanjat bekerja (Tohari, 2001: 105).

Penjelasan semantis melalui deskripsi tokoh juga tampak pada karakterisasi Cablaka. Cablaka memiliki arti jujur, terus terang, dan tidak menutup-nutupi sesuatu. Kata cablaka juga sangat identik dengan bahasa Banyumas. Bahkan nama lain dari bahasa Banyumasan adalah bahasa cablaka atau bahasa panginyongan. Identitas masyarakat Banyumas yang polos, jujur dan apa adanya menjadikan cablaka sebagai ruh yang dimiliki masyarakat Banyumas. Hal ini tergambar pula dalam tokoh cablaka pada novel Belantik yang tertera dalam kutipan berikut ini.

\begin{abstract}
"Bung Kanjat, anda agak ketinggalan zaman. Saya sudah mendegar dari kenalan di Jakarta, lama sebelum hal itu masuk siaran radio asing tersebut, "tanggap Drs. Cablaka, dosen ekonomi. " Yang saya dengar begini. Kelompok modal asing maupun domestik melihat pelobi tingkat tinggi yang bernama Bambung itu adalah berkembang menjadi masalah bagi mereka. Bagi mereka, orang semacam Bambung menjadi salah satu sebab kecenderungan ekonomi biaya tinggi, yang tentu saja tidak mereka sukai. Oleh karena itu mereka ingin mem-by pass dia. Mereka ingin mengurus penanaman modal dan sebagainya langsung ke pusatkekuasaan resmi. Maka mereka bikin ulah. Antara lain, mungkin memasok bahan penyiaran kepada wartawan radio asing dengan materi yang mendiskreditkan Bambung. Mereka pasti bisa melakukannya karena mereka sudah lama berhubungan dengan Bambung, dan cukup banyak tahu rahasia itu (Belantik, 2001:127).
\end{abstract}

Selain tokoh Cablaka, dalam novel Belantik juga dimunculkan tokoh Blakasuta. Blakasuta dalam Kamus Dialek Banyumas-Indonesia berarti tidak menutup-nutupi. Dalam novel tokoh Blakasuta digambarkan berprofesi sebagai pengacara.

Blakasuta mendengarkan dengan mulut terkatup dan mata sering melebar. Pengacara muda itu tampak terkejut karena Lasi, yang namanya sudah masuk koran dan dihubung-hubungkan dengan 
Bambung yang sedang disidik oleh kejaksaan, ternyata seorang perempuan Karangsoga. (Belantik, 2001:136).

Secara implisit Blakasuta merupakan karakter yang diharapkan mampu membuka kasus hukum. Hal ini tampak sejalan dengan pemaknaan leksikal yang menunjukkan bahwa "blakasuta" bermakna tidak menutupnutupi. Demikian juga dengan karakter yang dilekatkan pada tokoh Martacarub. Dalam cerita tokoh tersebut berprofesi sebagai pakar hukum pidana. Oleh karena itu, ia sering dimintai nasihat tentang hukum dan karakternya tidak berbeda dari tokoh Blakasuta. Adapun pada galibnya, Martacarub adalah nama lain Bawor atau Bagong (dalam wayang Gagrak Banyumas). Tokoh ini memiliki sifat lugu tapi juga lugas.

\section{Penutup}

Selain khasanah kebahasaan, kekayaan cerita rakyat seperti Babad Banyumas sebenarnya adalah lahan bagi penulis kreatif. Mitos-mitos yang menjamur di penjuru Banyumas adalah artefak yang seharusnya mampu diadaptasi. Bukakah Roro Mendut telah direkonstruksi YB Mangunwijaya menjadi fiksi sejarah yang menarik? Demikian pula Sangkuriang oleh Utuy Tatang Sontani? Lalu, mengapa cerita asli Ajibarang Banyumas, Gunungputri, tidak bisa menjadi teks baru yang menarik untuk dibaca?

Pengarang sah-sah saja meminjam teks lain sebagai bahan karyanya. Intertekstualitas toh tak mungkin dihindarkan dalam proses kreatif. Lihatlah, berapa banyak karya sastra modern dunia yang terpengaruh oleh Ulyses karya Homerus? Atau, berapa banyak karya sastra yang didasarkan pada mitologi, misalnya drama Yunani klasik Odipus Rex dan Electra.

Melihat hal tersebut, bukan tidak mungkin cerita-cerita lisan di wilayah Banyumas dapat diadaptasi menjadi drama-drama modern. Kekhasan itu tidak sekadar pada dialek tetapi juga pada unsur dramaturginya. Dialog sebagai unsur utama akan mampu mengekspresikan karakter Banyumas. Belum lagi jika ditambah pengoptimalan musik, tari, dan properti pentas (kostum). Ya, semua itu tergantung pada upaya para kreator merekonstruksi mitos-mitos Banyumasan. Perlu diingat bahwa mitos adalah cerminan prinsip-prinsip universal suatu kebudayaan atau "roh budaya".

Meski demikian, revitalisasi sastra Banyumas merupakan tugas besar semua pihak: para kreator, kritikus, pengajar, dan pemerhati sastra Banyumas. Proses tersebut sangat panjang dan tidak semudah membalik 
telapak tangan. Ada banyak tahap yang membutuhkan konsistensi semua pelaku budaya. Meski demikian harapan akan senantiasa ada; sastra Banyumasan tidak lagi dianggap ndesa karena dialek ngapak-ngapaknya tetapi menjadi karya adiluhung yang berisi roh kesederhanaan, kesatriaan, dan kelugasan wong Banyumas.

\section{Daftar Pustaka}

Http://id.wikipedia.org/wiki/Bahasa_Jawa_Banyumasan diakses pada 23 Juli 2013 pukul 09.02 wib.

Istiyani, Chatarina Pancer. 2004. Tubuh \& Bahasa: Aspek-Aspek Linguistik

Pengungkapan Pandangan Masyarakat Lewolema terhadap Kesehatan. Yogyakarta: Galang Press

Koderi, M. 1991. Banyumas Wisata dan Budaya. Purwokerto. CV Metro Jaya. Syarifuddin. 2008. "Mantra Nelayan Bajo:Cermin Pikiran Kolektif Orang Bajo di Sumbawa" . Disertasi. Yogyakarta: Fakultas Ilmu Budaya UGM

Tohari, Ahmad. 1989. Senyum Karyamin (Kumpulan Cerpen). Jakarta: Gramedia Pustaka Utama 2001. Di Kaki Bukit Cibalak. Jakarta: Gramedia Pustaka Utama . 2001. Belantik. Jakarta: PT Gramedia Pustaka Utama. . 2007. Kamus Dialek Banyumas-Indonesia Edisi Baru. Jakarta: PT

Gramedia Pustaka Utama. 